\title{
Recent cyanobacteria abundance in a large sub-tropical reservoir inferred from analysis of sediment cores
}

\author{
Daniela Gangi • María Sofía Plastani - Cecilia Laprida • Andrea Lami • \\ Nathalie Dubois · Facundo Bordet • Claudia Gogorza - Diego Frau • \\ Paula de Tezanos Pinto
}

Received: 24 December 2018/ Accepted: 7 January 2020

(C) Springer Nature B.V. 2020

\begin{abstract}
Salto Grande is a large South American reservoir on the border between Uruguay and Argentina that was impounded in 1979 and experiences recurrent, massive cyanobacteria blooms. A water-monitoring program was initiated 20 years after the dam was built, hence the causes and onset of cyanobacteria blooms remain poorly known. We collected two sediment cores from the old river channel in the reservoir $(\mathrm{z}=17 \mathrm{~m})$ and used physical, chemical and biological variables in the sediments,
\end{abstract}

Daniela Gangi and María Sofía Plastani share first authorship.

\section{Gangi}

Laboratorio de Limnología. Facultad de Ciencias Exactas y Naturales, Universidad de Buenos Aires, Buenos Aires, Argentina

\section{S. Plastani · C. Laprida}

Laboratorio de Sondeos de Ambientes Continentales y Marinos (SACMa) IDEAN (UBA-CONICET), Facultad de Ciencias Exactas y Naturales, Universidad de Buenos Aires, Buenos Aires, Argentina

\section{A. Lami}

CNR-Water Research Institute, Verbania, Italy

\section{N. Dubois}

Department of Earth Sciences, ETH Zürich, Zurich, Switzerland

\section{N. Dubois}

Surface Waters - Research and Management, Eawag, Swiss Federal Institute of Aquatic Science and Technology, Dübendorf, Switzerland along with existing limnological data, to explore the history of cyanobacteria in the sub-tropical water body. Cyanobacteria fossil pigments were present at low concentrations during the first 24 years after impoundment, but more than doubled thereafter. Phytoplankton abundance tracked shifts in cyanobacteria pigment concentration, indicating an overall increase in all primary producers. Several sediment variables indicate a decline in water quality after 2003 , such as increases in the number of photosynthetic sulfur bacteria and a reduction in sediment magnetic susceptibility. Akinetes (dormant cyanobacteria cells,

\footnotetext{
F. Bordet

Área de Gestión Ambiental, Gerencia de Ingeniería y Planeamiento, Comisión Técnica Mixta de Salto Grande (CTM), Concordia, Argentina

C. Gogorza

Centro de Investigaciones en Física e Ingeniería del Centro de la Provincia de Buenos Aires (CIFICENCONICET - UNCPBA - CICPBA), Tandil, Argentina

D. Frau

Instituto Nacional de Limnología (CONICET-UNL), Ciudad Universitaria Paraje El Pozo, 3000 Santa Fe, Argentina

P. de Tezanos Pinto ( $\square)$

Instituto de Botánica Darwinion. Buenos Aires, Argentina. Consejo Nacional de Investigaciones Científicas y Técnicas (CONICET), Buenos Aires, Argentina

e-mail: ptezanos@darwin.edu.ar
} 
Order Nostocales) in recent reservoir deposits were abundant and five species germinated under laboratory conditions, underscoring the ability of akinetes to initiate cyanobacteria blooms. The germinated assemblage reflected closely the composition of cyanobacteria blooms in the reservoir. Recorded increases in air temperature and decreases in wind speed, together with other variables (e.g. nutrients), can promote the large, recurrent cyanobacteria blooms. Invasion of the bivalve Limnoperna fortunei apparently promoted cyanobacteria blooms by preferential feeding on other phytoplankton taxa, and perhaps by altering nutrient concentrations and ratios. This work highlights the potential for using multiple variables in sediment cores from large reservoirs to better understand the responses of biota to multiple environmental stressors.

Keywords Akinetes - Cyanobacteria - Pigments · Paleolimnology $\cdot$ Reservoir

\section{Introduction}

Cyanobacteria blooms occur in many water bodies around the world and can have negative ecological (Huisman et al. 2005; Ibelings and Havens 2008) and economic impacts (Merel et al. 2013), as some blooms are toxic to wildlife and humans. Many studies indicate that recent increased intensities and frequencies of cyanobacteria blooms are responses to eutrophication (O'Neil et al. 2012; Taranu et al. 2015), but climate change (Paerl and Paul 2012), hydrologic changes (IPCC 2014) and biological invasions (Carpenter et al. 1995; Boltovskoy et al. 2013) can also increase risks of cyanobacteria blooms.

Regular monitoring is crucial for assessing changes in the magnitude, frequency and duration of cyanobacteria blooms in inland waters. Direct observations and monitoring programs, however, have usually been initiated only recently and often lack data of high temporal resolution, precluding an understanding of longer-term environmental changes in aquatic ecosystems (Dearing 2013). Paleolimnology, the stratigraphic study of variables in sediment cores from inland water bodies, can provide long-term perspectives on past ecological conditions, even prior to the initiation of monitoring programs (Williamson et al. 2009; Kowalewski et al. 2016).
Among paleolimnological variables, pigments in sediments can be used as indicators of past relative algae and cyanobacteria abundances (Riedinger-Whitmore et al. 2005; Kowalewski et al. 2016). RiedingerWhitmore et al. (2005) used sedimentary pigments, in combination with other sediment variables, to assess the timing and possible causes behind cyanobacteria proliferation in several sub-tropical water bodies in Florida, USA. In some of their lakes, abrupt pigment increases in sediments were linked to cultural eutrophication, whereas in other cases, long histories of high pigment concentrations reflected local edaphic (natural) conditions (Riedinger-Whitmore et al. 2005). Pigments in lake and reservoir sediments can also be used to infer past redox conditions (Guilizzoni 2012; McGowan 2013) and grazing pressure (Leavitt et al. 1993).

Among cyanobacteria, one group, the Order Nostocales, is capable of developing dormant cells called akinetes under unfavorable growth conditions. These specialized cells represent an important intermediate phase between past and future blooms, as akinetes form during blooms, can remain dormant, and then germinate to initiate new blooms (Legrand et al. 2017). Water bodies with large populations of planktonic cyanobacteria in the Order Nostocales usually possess large numbers of akinetes in their sediments (Hellweger et al. 2008). Akinetes in surface sediments can be used to assess the potential for development of new planktonic populations (Hellweger et al. 2008; Cirés et al. 2013), through quantification of akinetes in uppermost sediments and germination experiments.

During the twentieth century, extensive damming of rivers worldwide transformed many water bodies, formerly unsuitable for cyanobacteria growth, into artificial ecosystems where cyanobacteria proliferate (Znachor et al. 2006); mainly because of increased water retention times (Kalff 2002) and reduced turbulence. Today, many reservoirs around the world experience cyanobacteria blooms (Amé et al. 2003; Rahman et al. 2005; Znachor et al. 2006; Li et al. 2010; Joung et al. 2011; Te and Gin 2011).

Salto Grande reservoir, the focus of this study, is a large $\left(750 \mathrm{~km}^{2}\right)$, sub-tropical South American reservoir that experiences massive, recurrent blooms of cyanobacteria that belong to the Orders Chroococcales and Nostocales. Sporadic cyanobacteria blooms were observed in the reservoir after the dam was constructed in 1979 (Berón 1990), and by 2000-2002, 
cyanobacteria relative abundance was high (Chalar 2009). Massive, recurrent blooms have been documented since 2007 (O'Farrell et al. 2012; Bordet et al. 2017). The reservoir was also invaded by the filterfeeding bivalve Limnoperna fortunei (Boltovskoy et al. 2006) and the watershed has undergone major land use changes (Drozd and Arturi 2017).

The Salto Grande hydroelectric dam $\left(31.26^{\circ} \mathrm{S}\right.$ latitude, $57.93^{\circ} \mathrm{W}$ longitude) was built on the Uruguay River in 1979 , forming a large $\left(783 \mathrm{~m}^{2}\right)$, shallow $\left(\mathrm{z}_{\text {mean }}=6.4 \mathrm{~m}\right)$ reservoir between Argentina and Uruguay. Regular monitoring of reservoir water quality started only after year 2000, leaving an information gap about limnological conditions during the first 21 years of dam operation. The almost 2 decades of monitoring data from Salto Grande reservoir provide information about physical, chemical and biological water column variables (Table 1), yet prior to this study, sediments in the reservoir had

Table 1 Physical and chemical characteristics of the Salto Grande reservoir. For chemical variables, only the values of the river-like area of the reservoir, where the cores were obtained, never been investigated. Data collected since 2000 yielded important information about water quality in the reservoir, but it remains unclear whether cyanobacteria were abundant since the time of dam construction, or if they increased only later in the reservoir's history. Paleolimnological variables were studied to infer environmental conditions in the reservoir since the year of dam construction (1979), up to the year when regular monitoring was initiated (2000).

We analyzed two sediment cores from Salto Grande reservoir to explore the history of cyanobacteria populations in the water body. We used physical, chemical, and biological measures in the sediment, along with available historical environmental data, to address the following questions: (1) Have cyanobacteria in the reservoir increased since the dam was constructed, and if so, when did that occur? (2) What are the potential environmental drivers that trigger

are presented. Nutrient concentrations are expressed as mean and standard deviation

\begin{tabular}{|c|c|c|}
\hline Salto Grande reservoir & Lat. S $29^{\circ} 43^{\prime}$ to $31^{\circ} 12^{\prime}$, Long. W $57^{\circ} 06^{\prime}$ to $57^{\circ} 55^{\prime}$ & \\
\hline Reservoir area & $750 \mathrm{~km}^{2}$ & Bordet et al. (2017) \\
\hline Reservoir basin area & $224,000 \mathrm{~km}^{2}$ & Chalar (2009) \\
\hline Reservoir length & $144 \mathrm{~km}$ (with its major axis running in a NS direction) & Bordet et al. (2017) \\
\hline Reservoir physiognomy & Dendritic; one main channel and 5 lateral arms & O’Farrell and Izaguirre (2014) \\
\hline Reservoir mean volume & $5000 \mathrm{hm}^{3}$ & Bordet et al. (2017) \\
\hline Depth & Maximum: $35 \mathrm{~m}$; average: $6.4 \mathrm{~m}$ & O’Farrell et al. (2012) \\
\hline Mean water retention time & $\begin{array}{l}2 \text { weeks (during low-water periods this can increase to } 9 \text { weeks } \\
\text { or more) }\end{array}$ & Chalar (2006); O’Farrell et al. (2012) \\
\hline $\begin{array}{l}\text { Average yearly water } \\
\text { discharge }\end{array}$ & $4640 \mathrm{~m}^{3} \mathrm{~s}^{-1}$ (although with pronounced seasonal variations) & Bordet et al. (2017) \\
\hline $\mathrm{pH}$ & Slightly alkaline & $\begin{array}{l}\text { O'Farrell et al. (2012); Bordet et al. } \\
\text { (2017) }\end{array}$ \\
\hline Trophic level & Eutrophic & $\begin{array}{l}\text { O'Farrell et al. (2012); Bordet et al. } \\
\text { (2017) }\end{array}$ \\
\hline Mixing regime & $\begin{array}{l}\text { Polymictic (with short thermal stratification during low } \\
\text { discharge periods) }\end{array}$ & Bordet et al. (2017) \\
\hline Nitrogen & $\begin{array}{l}\text { Total: } 850 \pm 490 \mu \mathrm{g} \mathrm{L}^{-1} ; \text { dissolved inorganic: } \\
\quad 570 \pm 260 \mu \mathrm{g} \mathrm{L}^{-1}\end{array}$ & Bordet et al. (2017) \\
\hline Phosphorus & Total: $30 \pm 20 \mu \mathrm{g} \mathrm{L}^{-1}$; reactive soluble: $20 \pm 10 \mu \mathrm{g} \mathrm{L}^{-1}$ & Bordet et al. (2017) \\
\hline Mean air temperature & Annual: $19^{\circ} \mathrm{C}$ winter: $7{ }^{\circ} \mathrm{C}$; summer: $30^{\circ} \mathrm{C}$ & Bordet et al. (2017) \\
\hline Mean annual rainfall & $1260 \mathrm{~mm}$ & O’Farrell et al. (2012) \\
\hline Local winds & $\begin{array}{l}\text { NE direction; mean monthly velocities between } 10 \text { and } \\
12 \mathrm{~m} \mathrm{~s}^{-1}\end{array}$ & Bordet et al. (2017) \\
\hline
\end{tabular}


cyanobacteria blooms? We quantified akinete concentrations in recent deposits and in conjunction with laboratory germination experiments addressed the following questions: (3) How dense is the "akinete bank" in recent sediments? (4) Do relative abundances of germlings (filaments arising from germinated akinetes) reflect the cyanobacteria populations in the water column?

\section{Materials and methods}

Field sampling

Field sampling was carried out in Austral summer 2015, in the river-like area of the Salto Grande reservoir (Fig. 1). This area was selected because it has the greatest water depths (average: 10-20 m). Sediment cores were collected from a Regnicoli 630 boat, anchored at a water depth of $17 \mathrm{~m}$. We obtained two cores: Core $1\left(\mathrm{C} 1\right.$, at $\left.31.20761^{\circ} \mathrm{S}, 57.91955^{\circ} \mathrm{W}\right)$, and Core $2\left(\mathrm{C} 2\right.$ at $\left.31.20806^{\circ} \mathrm{S}, 57.91857^{\circ} \mathrm{W}\right)$. Cores were taken with a hammer corer that had a $\sim 1-\mathrm{m}$ long, 7.5-cm-ID core barrel. When the cores were brought to the reservoir surface, the sediment-water interface in both was intact, and no degassing occurred. Cores were immediately covered with dark plastic to prevent exposure to light and were transported from the study site to the laboratory in a vertical position to prevent sediment mixing. In the laboratory, the cores were stored in a dark room at $4{ }^{\circ} \mathrm{C}$ to prevent pigment degradation.

Physical, geochemical and biological variables

Before the cores were opened, they were X-rayed to identify internal sediment structures. Afterwards, cores were split lengthwise, photographed, and their stratigraphy was described. Colors were defined according to the Munsell Soil Color Chart. Volume magnetic susceptibility was measured at $0.5-\mathrm{cm}$ intervals using a Bartington MS3 and results were used to establish stratigraphic correlation between cores, and as a first-order indicator of the concentration of magnetic (sensu lato) minerals in the sediment (Thompson and Oldfield 1986). Next, each core was subsampled at $1-\mathrm{cm}$ resolution using a small lab spatula. Core chronology was determined by ${ }^{210} \mathrm{~Pb}$ dating. Ten subsamples from each core, of 4-5 g dry weight, were measured on a high-purity germanium (HPGe), well-type gamma spectrometer (Canberra Industries Inc.) at EAWAG, Switzerland. (a)

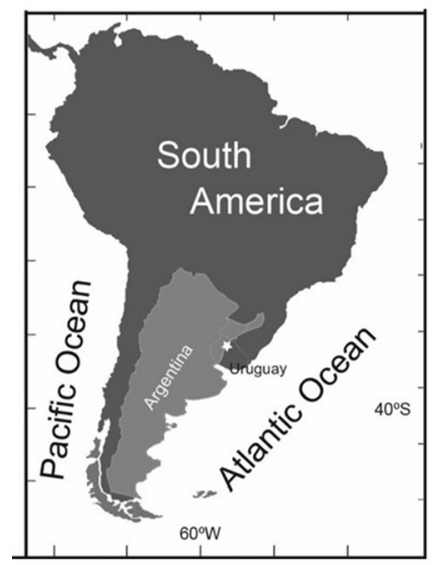

(b)

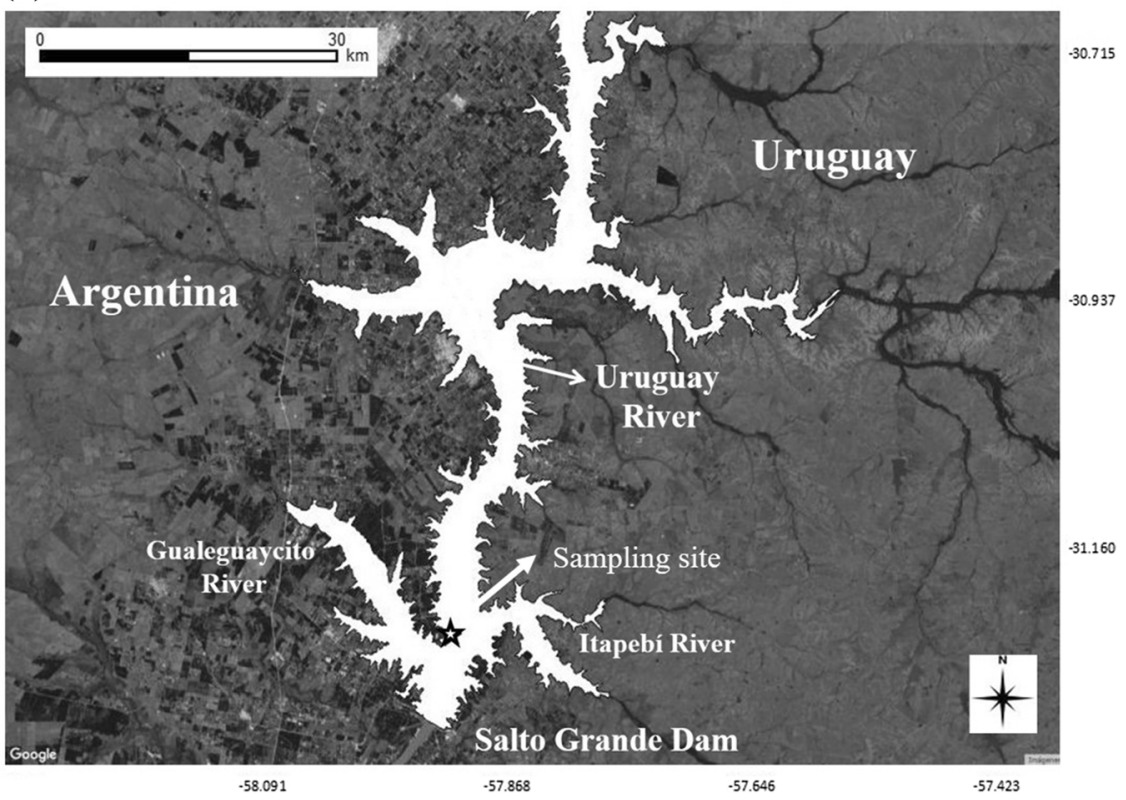

Fig. 1 Map of the Salto Grande reservoir showing the location (a) and morphology (b) of the reservoir. The star depicts the sampling site 
Water content was measured on each 1-cm-resolution sample in both cores, by drying sediments at $60{ }^{\circ} \mathrm{C}$ for at least $24 \mathrm{~h}$. Next, organic matter content was estimated by loss-on-ignition (Heiri et al. 2001). Sedimentary pigments were measured in each 1-cmresolution sample from $\mathrm{C} 1$. Pigments were extracted from $\sim 1 \mathrm{~g}$ of wet sediment with $5 \mathrm{~mL}$ of $90 \%$ acetone solution overnight in the dark at one atmosphere of nitrogen. Then, sediments were centrifuged at $3000 \mathrm{rpm}$ for $10 \mathrm{~min}$. The extract was used to quantify pigments using High Pressure Liquid Chromatography, with an Ultimate 3000 system (ThermoFisher) that consisted of a quaternary pump, an autosampler and a DAD detector. The elution program and the method for pigment identification, taxonomic specificity and quantification followed the procedures of Lami et al. (2009). The herbivory index, i.e. a proxy for grazing pressure, was calculated as the pigment ratio (chl a + pheophythin a)/pheophorbide (Leavitt et al. 1993). Finally, the wavelength absorption ratio $430 \mathrm{~nm}: 410 \mathrm{~nm}$ was used as an index of pigment preservation, which can be used in cases where lakes are not acidified (Lami et al. 2000), as is the case for the Salto Grande reservoir (Table 1). Stratigraphic zones for each variable were determined using Optimal Partition (Birks and Gordon 1985). Statistical significance was determined by comparison against null models estimated by the Broken-stick model SSQ with the program BSTICK version 1.0 (Bennett 1996).

Sediment age-depth relationships

and sedimentation rate calculations

To establish sediment age-depth relationships and calculate sedimentation rates, the constant flux constant sedimentation rate (CF-CSR), constant initial concentration (CIC) and constant rate of supply (CRS) models were utilized. The CRS model assumes a constant flux of excess ${ }^{210} \mathrm{~Pb}$ to the sediment, but can accommodate variable sedimentation rate. In this model, the sediment age at depth is given by the ratio of excess ${ }^{210} \mathrm{~Pb}$ activity below that point to the total excess ${ }^{210} \mathrm{~Pb}$ activity in the sediment column (Appleby and Oldfield 1983). Thus, the CRS model is applicable to longer-term sedimentation, i.e. when at least $\sim 100$ years of sediment has accumulated. Because the dam was built in 1979, the reservoir sediment column is shorter than the equilibrium depth (age), i.e. the depth at which total ${ }^{210} \mathrm{~Pb}$ would be in equilibrium with the supported ${ }^{210} \mathrm{~Pb}\left({ }^{226} \mathrm{Ra}\right)$, which would require an age of about five ${ }^{210} \mathrm{~Pb}$ half-lives, or $\sim 110$ years. Thus we could not measure the "complete" unsupported core inventory. Because the total unsupported inventory ${ }^{210} \mathrm{~Pb}$ is important for application of the CRS model (Appleby 2001; MacKenzie et al. 2011), we opted instead to apply the constant initial concentration (CIC) model (Pennington et al. 1976). The CIC model assumes that the initial concentration of excess ${ }^{210} \mathrm{~Pb}$ remained constant throughout the history of sediment accumulation, regardless of changes in the rate of sediment deposition (Pennington et al. 1976). The CIC model assumes that the sedimentation rate has remained constant through time, or that the flux of excess ${ }^{210} \mathrm{~Pb}$ changed proportionally with changes in sediment accumulation. The CIC model has been applied successfully in aquatic environments where excess ${ }^{210} \mathrm{~Pb}$ inputs are dominated by fluxes of sediment, and associated ${ }^{210} \mathrm{~Pb}$, mobilized from the surrounding catchment, as can be the case with urban reservoirs (McCall et al. 1984). When excess ${ }^{210} \mathrm{~Pb}$ fluxes and sediment accumulation rates are both constant, the CRS and CIC models converge to the $\mathrm{CF}-\mathrm{CSR}$ model and the excess ${ }^{210} \mathrm{~Pb}$ activity declines exponentially with mass depth (Appleby 2001). Since ${ }^{210} \mathrm{~Pb}$ decays logarithmically with time from its initial activity, with a decay constant of $0.03114 \mathrm{a}^{-1}$, the sediment age at any depth is given by: $\mathrm{t}_{\mathrm{z}}=(l / k) \operatorname{Ln}\left(\mathrm{A}_{0} /\right.$ $\mathrm{A}_{1}$ ) where $\mathrm{t}_{\mathrm{z}}=$ age at depth $\mathrm{z}, k={ }^{210} \mathrm{~Pb}$ decay constant, $\mathrm{A}_{0}=$ initial unsupported ${ }^{210} \mathrm{~Pb}$ activity per unit mass, and $\mathrm{A}_{1}=$ unsupported ${ }^{210} \mathrm{~Pb}$ activity per unit mass at depth $\mathrm{z}$.

\section{Historical environmental data}

Historical data on air temperature, wind speed, and precipitation were provided by the weather station EEA, INTA (Estación Experimental Agropecuaria, $\left.31.22531^{\circ} \mathrm{S}, 58.06551^{\circ} \mathrm{W}\right)$, located about $20 \mathrm{~km}$ southwest of the Salto Grande reservoir, and were available from 1967, prior to dam construction, to 2017. Water level and water flow data were provided by the Comisión Técnica Mixta and measured at the Salto Grande reservoir, and were available from 1994, 15 years after the dam was constructed, to 2017 . We calculated annual mean values for air temperature, wind speed, water flow, and water level, and determined cumulative annual precipitation values. Temporal trends in these variables were analyzed 
statistically using the non-parametric Mann-Kendall test (Gilbert 1987).

Cyanobacteria abundance

The three uppermost samples $(3-2,2-1,1-0 \mathrm{~cm})$ in cores $\mathrm{C} 1$ and $\mathrm{C} 2$ were used to assess recent cyanobacteria abundance. To characterize akinete density in each of the samples, about $0.5 \mathrm{~g}$ of wet sediment was diluted in $50 \mathrm{~mL}$ distilled water, and fixed with Lugol's solution. Akinete quantification was performed using a Palmer Cell with a Zeiss Standard 18 light microscope, at a magnification of $400 \times$. At least three chambers were counted for each sample. Akinete density was first calculated as akinetes $\mathrm{mL}^{-1}$, applying the formula: Akinetes $\mathrm{mL}^{-1}=\left(\mathrm{C} *\right.$ a) $\mathrm{F}^{-1}$, where $\mathrm{C}=$ total number of akinetes counted (unit $=$ akinetes), $\mathrm{a}=$ the area of view, derived from the magnification and microscope used, and the depth of the counting chamber $\left(\mathrm{mL}^{-1}\right)$, and $\mathrm{F}=$ number of fields counted. Next, akinete density was converted into akinetes $\mathrm{g}^{-1}$ dry weight, which accounts for the dilution applied $(50 \mathrm{~mL}$ water) and the water content of sediments.

The akinete germination experiment was run under controlled laboratory conditions. Each treatment was run with three pseudo-replicates $(2$ cores $* 3$ layers $[3-2,2-1,1-0 \mathrm{~cm}] * 3$ pseudo-replicates $=18$ experimental units). Each experimental unit contained $1 \mathrm{~g}$ of wet sediment in $150 \mathrm{~mL}$ of sterile WC culture medium (Guillard 1975). Total nitrogen and total phosphorus concentrations in the standard WC culture medium were modified to mimic historical nutrient levels in the reservoir; all other nutrient concentrations were those of WC medium. The experimental units were exposed to: light $\left(100 \mu \mathrm{mol}\right.$ photon $\left.\mathrm{m}^{-2} \mathrm{~s}^{-1}\right)$, temperature $\left(25^{\circ} \mathrm{C}\right)$ and photoperiod of $14 \mathrm{~h}$ light: $10 \mathrm{~h}$ dark. These variables are similar to the ones used in our previous laboratory studies run with cyanobacteria at the population and community level (de Tezanos Pinto and Litchman 2010a, b). The experiment was run in batch regime (without replenishment of the culture medium) and lasted 2 weeks. This time frame is recognized as sufficient for observing filaments in germination experiments (Cirés et al. 2013). At the onset and end of the experiment, $15 \mathrm{~mL}$ samples were taken and fixed with Lugol's solution. Sampling at the beginning of the experiment was done to test for the absence of filaments in the culture medium. If filaments are absent at the outset, then those observed at 15 days should have arisen from akinete germination, as well as from asexual reproduction of filaments from akinete germination. Filament density [filaments $\mathrm{mL}^{-1}=\left(\mathrm{C} *\right.$ a) $\mathrm{F}^{-1}$ ] was estimated using a Palmer cell with a Zeiss Standard 18 light microscope at a magnification of $160 \times$, and at least five counting chambers were counted for each sample. Results are expressed as relative filament density because filament density in the culture media may result from either the germination of one akinete or from the asexual division of previously germinated filaments.

\section{Results}

\section{Sediment description}

Combined analysis of the X-ray radiographs and sedimentology of $\mathrm{C} 1$ (Fig. 2a) showed cm-scale laminations (very thin to thin-bed) throughout the core. Some discrete, isolated burrows disrupted the primary fabric in the middle and base of core $\mathrm{C} 1$, but did not disrupt the laminations (Fig. 2a). Analysis of sediment color showed layers of light (red and dark reddish brown) and dark (dark brown to very dark grey) sediments, reflecting siliciclastic sediments. The $\mathrm{X}$-radiographs in $\mathrm{C} 2$ also showed $\mathrm{cm}$-scale laminations, but without burrows (Fig. 2b). In C2, the upper $35 \mathrm{~cm}$ were composed of intercalated light and dark, silty siliciclastic sediments, similar to those in $\mathrm{C} 1$. Sediments below $35 \mathrm{~cm}$, however, were composed of very dark (blue-black and dark gray) clayey silts with roots and terrestrial plant debris, which displayed the features of a mature soil (Fig. 2b). Organic matter and water content were in the range of $9-16 \%$ and 50-60\%, respectively, in both cores (Fig. 2a, b). In $\mathrm{C} 2$, in particular, organic matter was low below $35 \mathrm{~cm}$, i.e. in the underlying soils (Fig. 2b).

\section{Core chronologies and correlation}

In $\mathrm{C} 1$, excess ${ }^{210} \mathrm{~Pb}$ activity did not decrease with depth (Fig. 2a). In $\mathrm{C} 2$, the excess ${ }^{210} \mathrm{~Pb}$ activity profile displayed an overall exponential decrease with depth and was used to date the core. After removing an outlier at $20.5 \mathrm{~cm}$ depth, the CF-CSR model suggested a linear sedimentation rate of $0.67 \mathrm{~cm} \mathrm{a}^{-1}$ between 4.5 

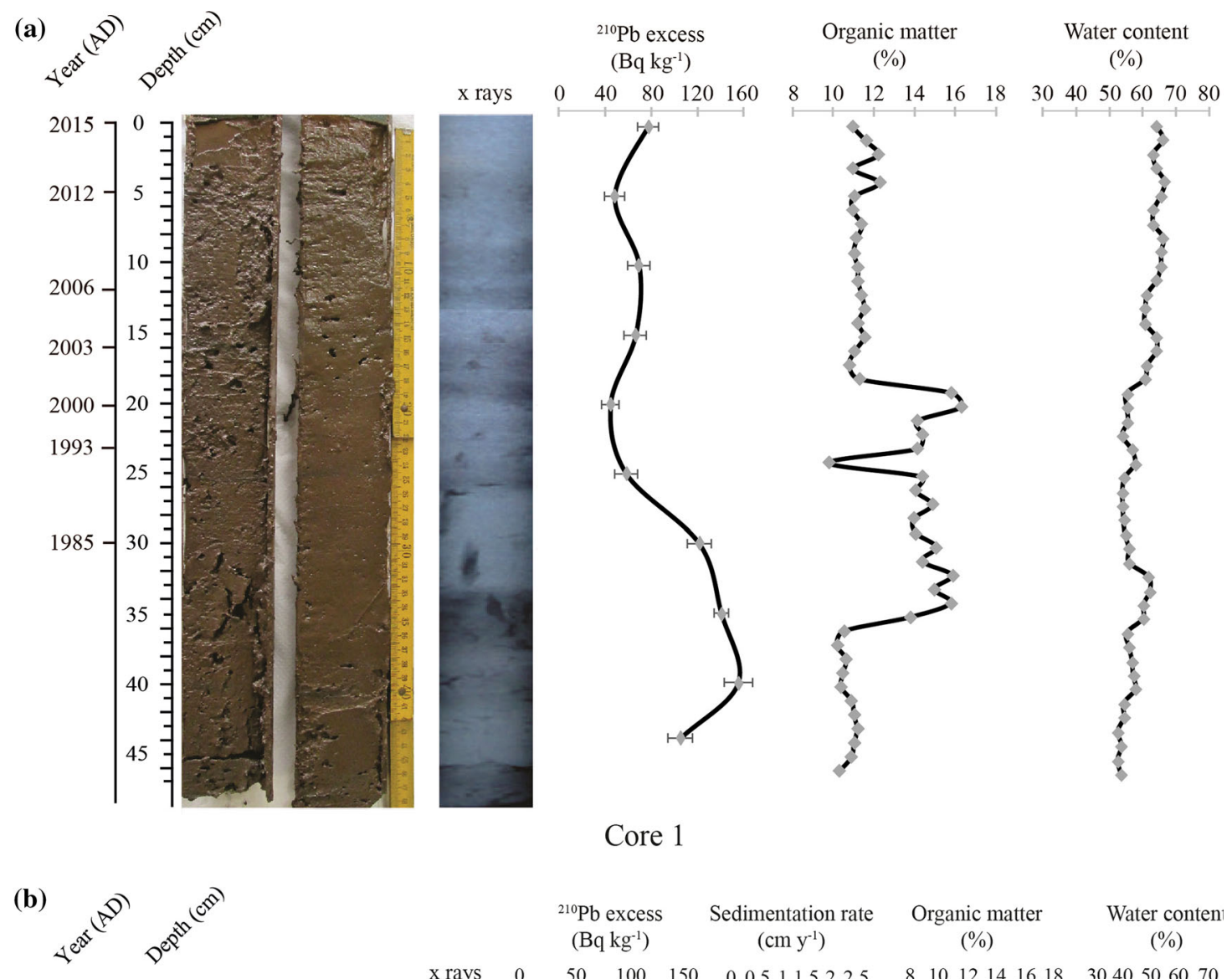

Core 1
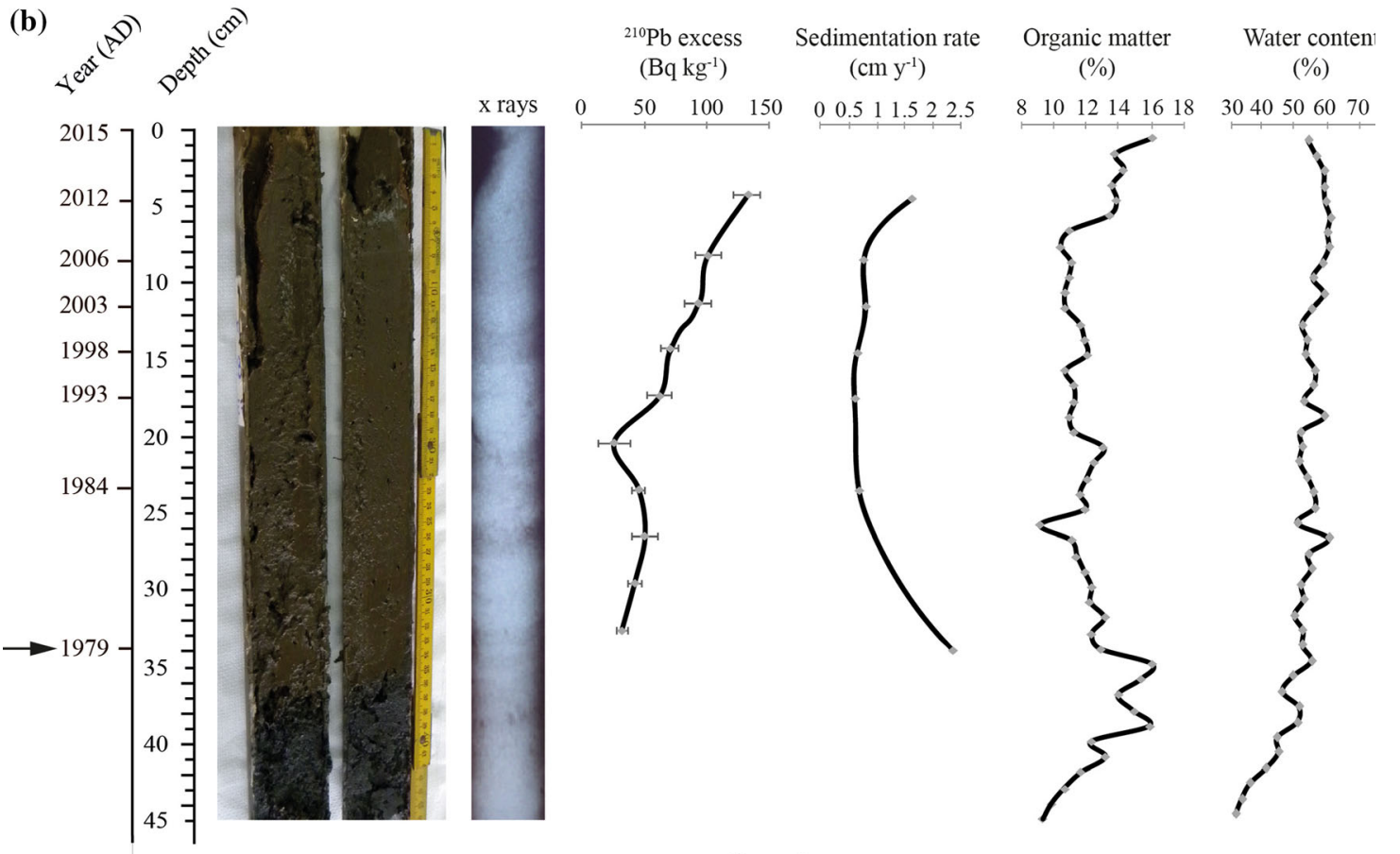

Fig. 2 Photograph of $\mathrm{X}$-ray view, ${ }^{210} \mathrm{~Pb}$ activity curve (with the error bars), organic matter (LOI) and water content for cores $\mathrm{C} 1$ (a) and C2 (b). Linear sedimentation rate is included for $\mathrm{C} 2$. The

\section{Core 2}

black arrow in C2 (b) depicts the onset reservoir sedimentation above underlying soil (blue-black color in the photograph). (Color figure online) 
and $32.5 \mathrm{~cm}\left(\mathrm{R}^{2}=0.96\right)$. The final age model was established using two anchor points, in conjunction with the CIC model (Fig. 2b): (1) surface sediment $(0 \mathrm{~cm})$ was assigned a date of 2015 , i.e. the coring year, and (2) the transition between soil and lacustrine sediments $(35 \mathrm{~cm})$ was assigned a date of 1979 , the year the dam was constructed. Using only these two anchor points yields a mean linear sedimentation rate of $0.94 \mathrm{~cm} \mathrm{a}^{-1}$, somewhat higher than the value from the CF-CSR model $\left(0.67 \mathrm{~cm} \mathrm{a}^{-1}\right)$. According to the CF-CSR model, linear sedimentation rate was high when the dam was constructed (1979) and then declined until 1984. Thereafter it was stable until 2006, but increased afterwards (Fig. 2b). The ${ }^{137} \mathrm{Cs}$ activities were below detection limit in both cores, which is not surprising for sediments from the Southern Hemisphere deposited $>15$ years after the peak year of atmospheric bomb testing, 1963.

Core correlation using magnetic susceptibility was based on five tie points above $27 \mathrm{~cm}$ in $\mathrm{C} 2$ and $32 \mathrm{~cm}$ in $\mathrm{C} 1$ (Fig. 3). Correlation enabled establishment of an age model for $\mathrm{C} 1$, using the chronology of $\mathrm{C} 2$ (Fig. 3). In both cores, magnetic susceptibility declined by half after 2003 (Fig. 3). In C2, magnetic susceptibility was very low in sediments below $35 \mathrm{~cm}$ (1979), i.e. in the underlying soils (Fig. 3).

\section{Fossil pigments}

Pigments in sediments showed two significant zones, one from 1979 to 2003 and another from 2003 to 2015 (Fig. 4). Specific pigments for cyanobacteria, i.e. echinenone, zeaxanthin and myxoxanthophyll, were present throughout the core. Concentrations were low from 1979 to 2003, but increased after 2003 by 2.5- to 3-fold (Fig. 4). Likewise, pigments linked to phytoplankton (beta carotene), eukaryotic algae (diatoms, cryptophytes and chlorophytes) and photosynthetic sulfur bacteria were present at low concentrations from 1979 to 2003, but increased > 2.5-fold after 2003

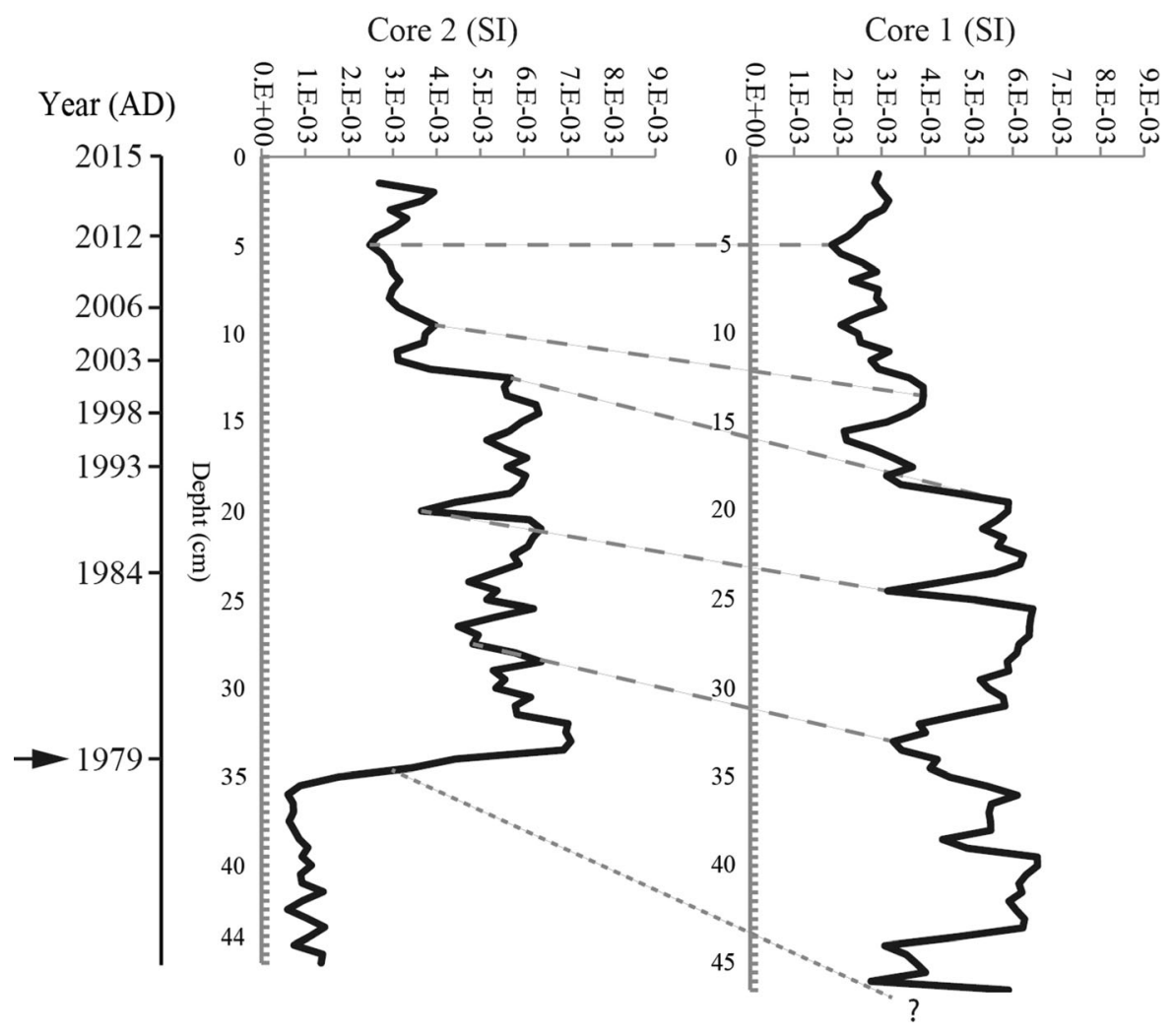

Fig. 3 Magnetic susceptibility and cross correlation of cores $\mathrm{C} 1$ and $\mathrm{C} 2$. Five tie points (dashed lines) enabled dating of $\mathrm{C} 1$ using the ${ }^{210} \mathrm{~Pb}$ chronology of $\mathrm{C} 2$. The black arrow in $\mathrm{C} 2$ depicts the shift between soil and lacustrine sediments, below which the magnetic susceptibility is very low 


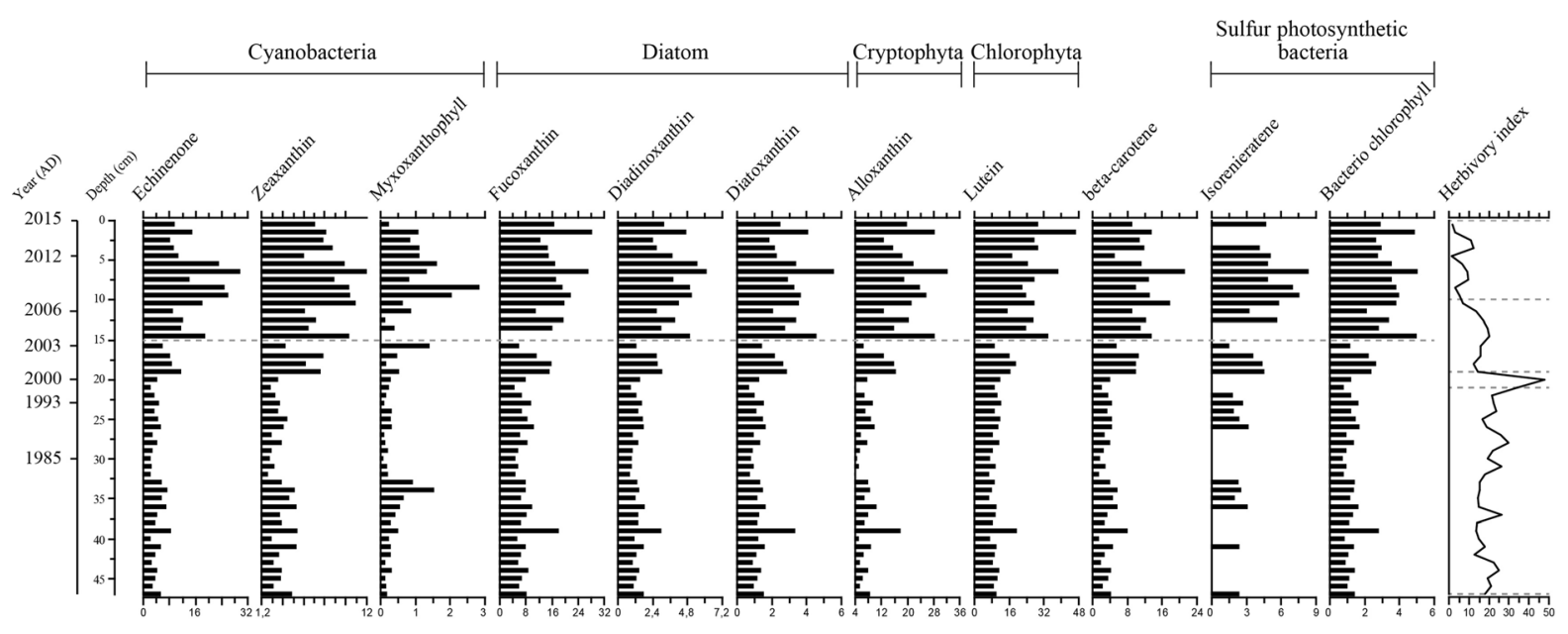

Fig. 4 Pigments denoting carotenoids specific for cyanobacteria, bacteria and phytoplankton (nMoles $\mathrm{g}^{-1}$ LOI) sorted by taxonomic affinity, and the herbivory index, (chl

(Fig. 4). The contribution of photosynthetic sulfur bacteria pigments was always low (mean isorenieratene concentration before and after $2003=2.4$ and 5.5 nMoles $\mathrm{g} \mathrm{LOI}^{-1}$, respectively, and mean bacterio-chlorophyll before and after $2003=1.3$ and 3.5 nMoles g LOI ${ }^{-1}$, respectively) (Fig. 4).

The radiation absorption ratio $430 \mathrm{~nm}: 410 \mathrm{~nm}$ in the sediment profile displayed values just below 1.0 (mean $=0.84$, range $=0.75-0.89$ ), without major changes before and after 2003 (Fig. 5). Values of the radiation absorption ratio $430 \mathrm{~nm}: 410 \mathrm{~nm}$ near 1.0 indicate generally good preservation (Lami et al. 2000). The herbivory index (HI), for which lowest values indicate higher grazing (Leavitt et al. 1993), showed four significant zones, with an overall trend of increased grazing through time (Fig. 4). The four significant zones were: 1979-1997 (high and constant HI, low grazing), 1997-2001 (highest HI values, low grazing), 2001-2009 (decreased HI values, high grazing) and 2009-2015 (lowest HI values, highest grazing) (Fig. 4).

Historical environmental data

Mean annual air temperature increased significantly throughout the period analyzed (tau: $0.321, p=0.002$ ) by about $0.5-1{ }^{\circ} \mathrm{C}$ (Fig. 6), with a period of lower annual mean temperatures from 1968 to 1992 $\left(<19^{\circ} \mathrm{C}\right)$ and an increasing trend from 1993 to 2009 (>19 ${ }^{\circ} \mathrm{C}$ ) (Fig. 6). Mean annual wind speed, a + pheophythin a)/pheophorbide, for which lower values denote higher grazing on phytoplankton. Dashed lines separate significantly different zones for the variables analyzed

decreased significantly (tau: 6.04, $p<0.0001$ ) by about 44\% from 1967 to 2017: values were highest in $1967\left(8.5 \mathrm{~km} \mathrm{~h}^{-1}\right)$, intermediate up to $1985(<8.5$ $\left.>6.05 \mathrm{~km} \mathrm{~h}^{-1}\right)$, and lowest $\left(<5.5 \mathrm{~km} \mathrm{~h}^{-1}\right)$ after 1985 (Fig. 6). There was no significant trend in annual precipitation (tau: $0.14, p=0.130$ ), with values ranging between 786 and $2193 \mathrm{~mm}$ (Fig. 6). Mean annual values of water discharge and water level also yielded non-significant trends (tau: 0.254, $p=0.088$, tau: $-0.210, p=0.160$, respectively) with higher values in the intervals 1994-2005 and 2012-2017, and lower values from 2004 to 2012 (Fig. 6).

\section{Current cyanobacteria abundance}

Akinete abundance in the six sediment samples analyzed ranged from $3.5 \times 10^{4}$ to $1.8 \times 10^{5}$ akinetes $\mathrm{g}^{-1}$ dry, with a mean and standard deviation of $9.2 \times 10^{4} \pm 5.7 \times 10^{4}$ akinetes $\mathrm{g}^{-1}$ dry. We did not observe colonies of Microcystis spp. (Order Chroococcales) in the six sediment samples.

At the onset of the germination experiment, we found no filaments in the culture medium of any of the 18 experimental units $(2$ cores $* 3$ depths $* 3$ pseudoreplicates). After 2 weeks, at the end of the experiment, we found filaments of five species: Dolichospermum planctonicum (Brunnthaler) Wacklin, L. Hoffmann \& Komárek, D. circinalis Rabenhorst ex Bornet et Flahault and D. cf. pseudocompactum (M. Watanabe), Cuspidothrix issatschenkoi (Usacev) 


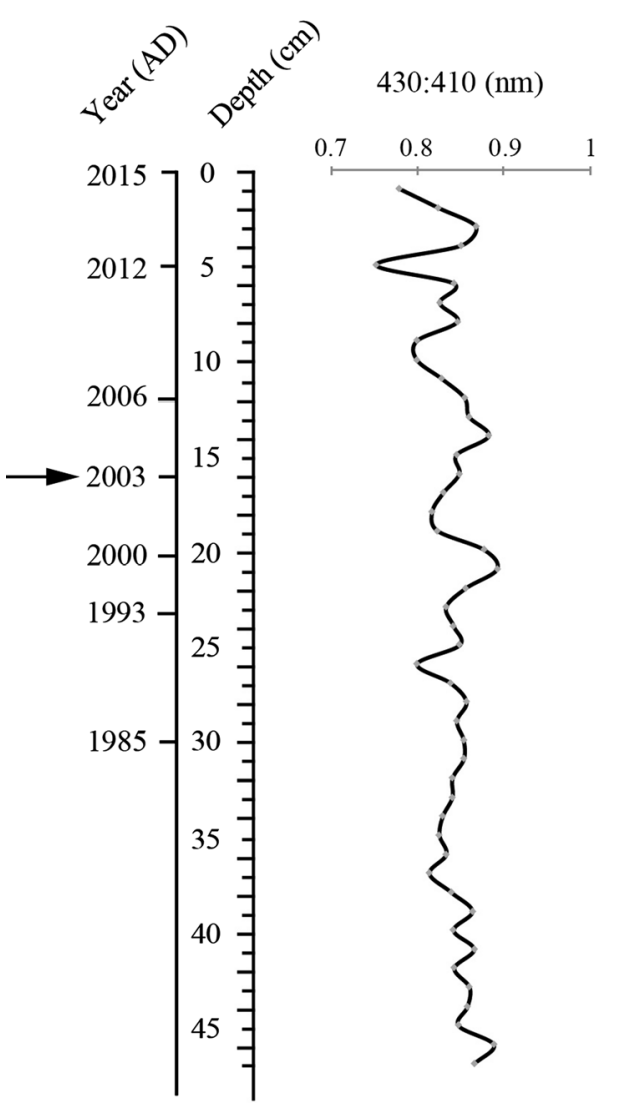

Fig. 5 Depth versus the radiation absorption ratio $430 \mathrm{~nm}: 410 \mathrm{~nm}$, an index of pigment preservation, for which values close to 1.0 indicate high pigment preservation. The arrow depicts the year 2003, when the shift towards increased productivity occurred. Note that the pigment preservation remains relatively constant before and after 2003

Rajaniemi, Komárek, Willame, Hrouzek, Kastovská, Hoffmann \& Sivonen and Aphanizomenon sp. All 18 samples still lacked colonies of Microcystis spp. Filament relative abundances at day 15 were rather similar across samples (Fig. 7). The species with the highest relative contribution was $D$. planctonicum (mean 58\%), followed by Cuspidothrix and D. circinalis (means of $20 \%$ and $17 \%$, respectively), and smaller contributions of Aphanizomenon and $D$. cf. pseudocompactum (means of $3.5 \%$ and $1.6 \%$, respectively) (Fig. 7). The three Dolichospermum species together represented about $76 \%$ of Nostocales abundance (Fig. 7).

\section{Discussion}

Core 2 (C2) was composed of a pre-inundation soil that was overlain by lacustrine sediments. The former was characterized by dark color, presence of roots, low values of magnetic susceptibility, and low organic matter content. Core $1(\mathrm{C} 1)$, however, was composed exclusively of lacustrine sediments. X-ray analysis revealed laminae in both cores, which was confirmed by visual inspection of the sediments. The few burrows observed in $\mathrm{C} 1$ did not cause substantial bioturbation, as shown by the persistence of laminations, the ability to match the magnetic susceptibility records between cores, and the clear structure of the pigment profile. Although ${ }^{210} \mathrm{~Pb}$ activity was measured in both cores, a reliable ${ }^{210} \mathrm{~Pb}$ chronology could not be established for $\mathrm{C} 1$ because excess ${ }^{210} \mathrm{~Pb}$ activity did not decrease with depth in the core. In $\mathrm{C} 2$, however, excess ${ }^{210} \mathrm{~Pb}$ activity displayed a generally exponential decrease with depth and was used to date the sediments and calculate sedimentation rate. Linear sedimentation rate was high right after dam construction, stabilized thereafter, and showed a marked increase again in recent years.

We dated $\mathrm{C} 1$, based on the chronology of C2, by correlating the magnetic susceptibility profiles between cores, using five tie points. Magnetic susceptibility, used as a first-order indicator of the concentration of magnetic (sensu lato) minerals (Thompson and Oldfield 1986), dropped by half after 2003 in both cores. This decline in magnetic minerals (Thompson and Oldfield 1986) was probably related to reducing conditions and concomitant destruction of ferrimagnetic grains by diagenesis, associated with sulfate reduction (Kawamura et al. 2007). More studies, however, are needed to confirm this interpretation.

Fossil pigments in the cores enabled us to infer what happened between dam construction in 1979, and the onset of the limnological monitoring program in 2000, thereby filling in the 21-year information gap. Cyanobacteria fossil pigments echinenone, zeaxanthin and myxoxanthophyll were present in low abundances during the first 24 years after dam construction. The data confirm that blooms occurred in the reservoir immediately after the dam was constructed, but blooms at that time were evidently sporadic (Berón 1990). By 2000-2002, however, cyanobacteria dominated the phytoplankton assemblage (Chalar 2009). A large change occurred in 2003, and is documented by a 

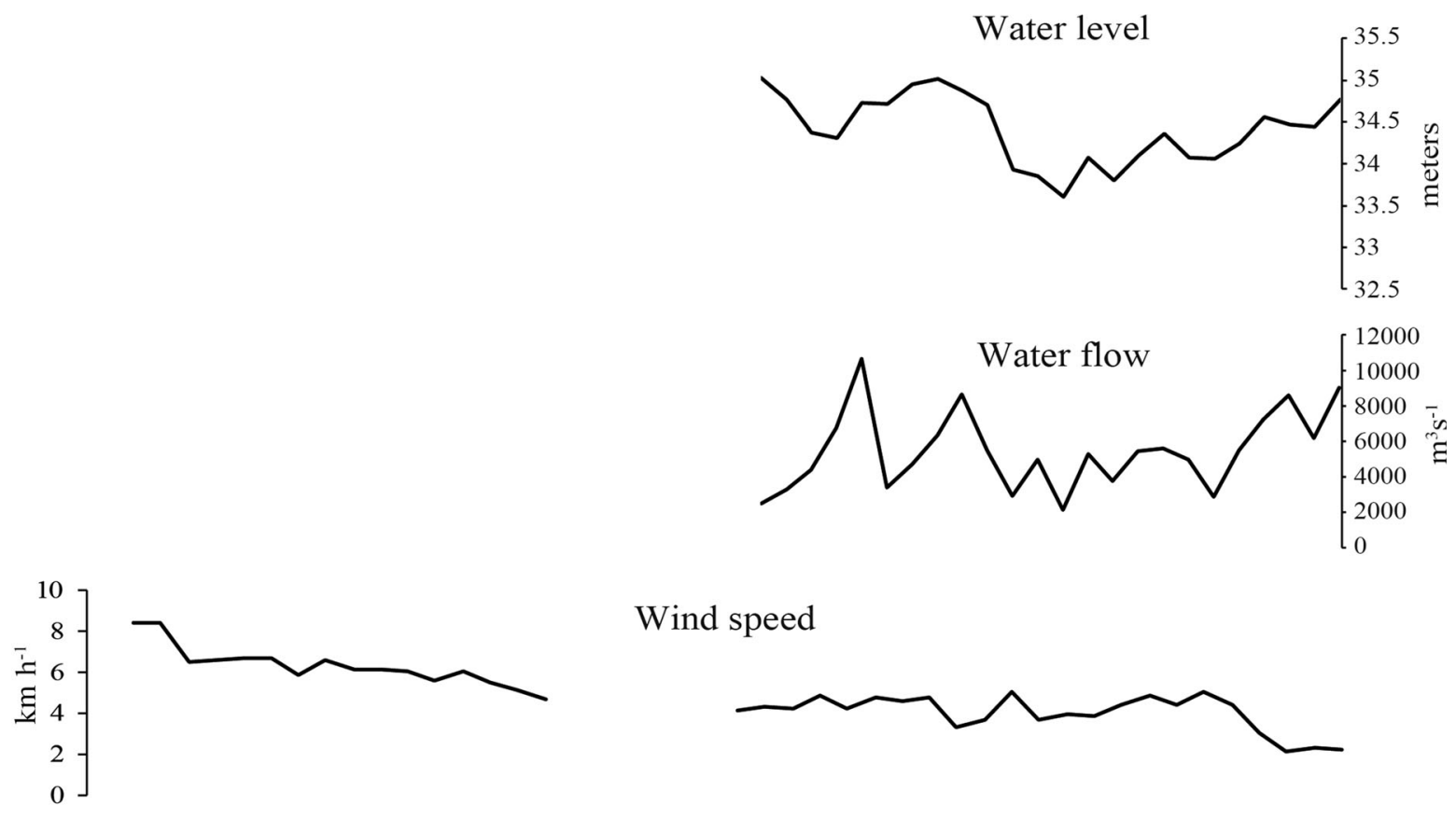

Wind speed
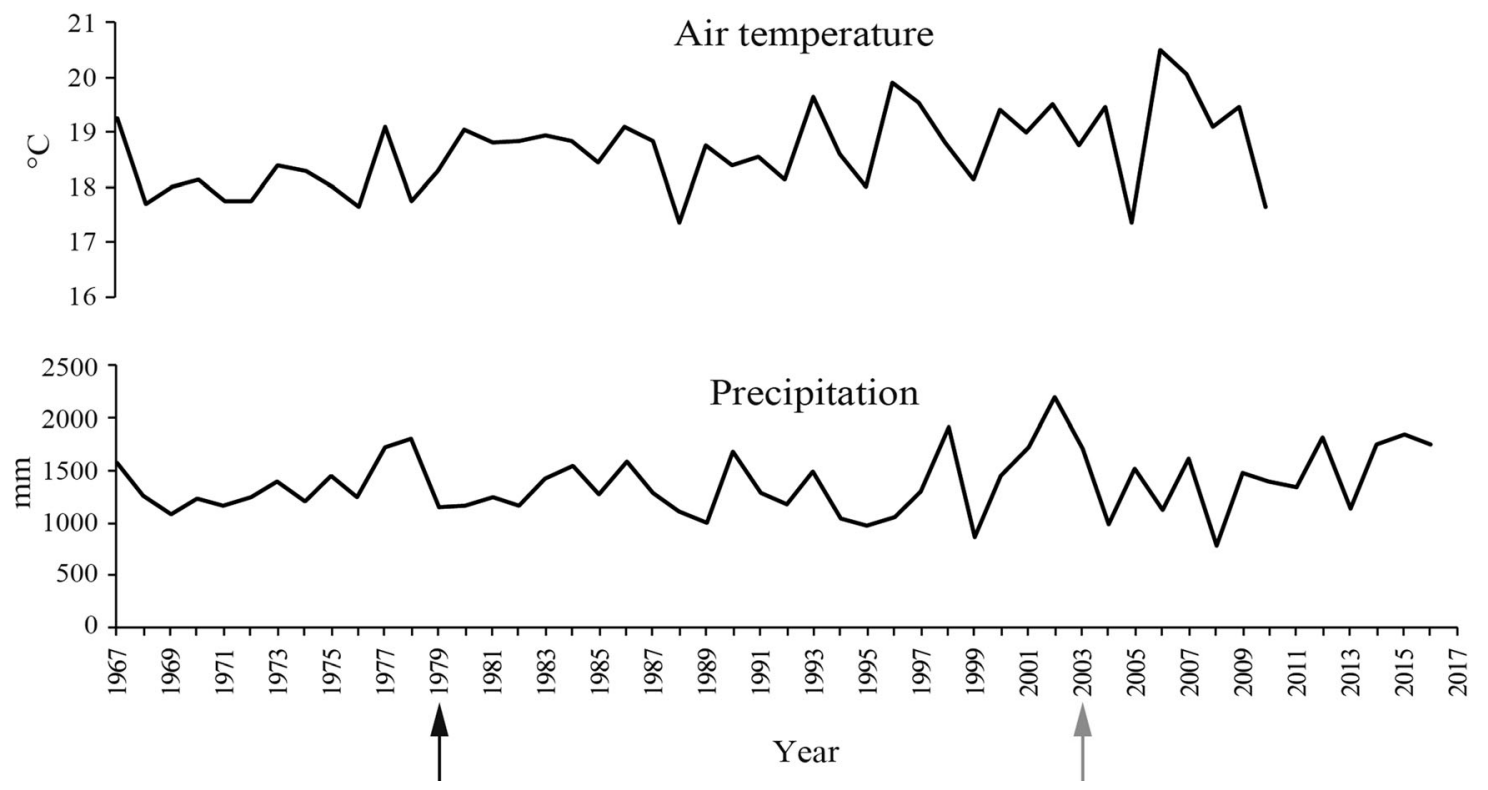

Fig. 6 Temporal trends through time for annual mean air temperature (significant increase, $p<0.05$ ), annual mean wind speed (significant decrease, $p<0.05$ ), annual precipitation, annual mean water flow and annual mean water level. The dark

2.5- to 3-fold increase in cyanobacteria pigment concentrations. This paleolimnological result is consistent with what was observed in the water monitoring program, which shows that blooms have been massive and recurrent since at least 2007 (O'Farrell arrow denotes the year when the dam was built (1979) and the gray arrow denotes the year when the shift towards increased cyanobacteria occurred (2003)

et al. 2012; Bordet et al. 2017). As observed for pigments of cyanobacteria, pigments of eukaryotic phytoplankton (diatoms, chlorophytes, cryptophytes) and photosynthetic sulfur bacteria were present at low 


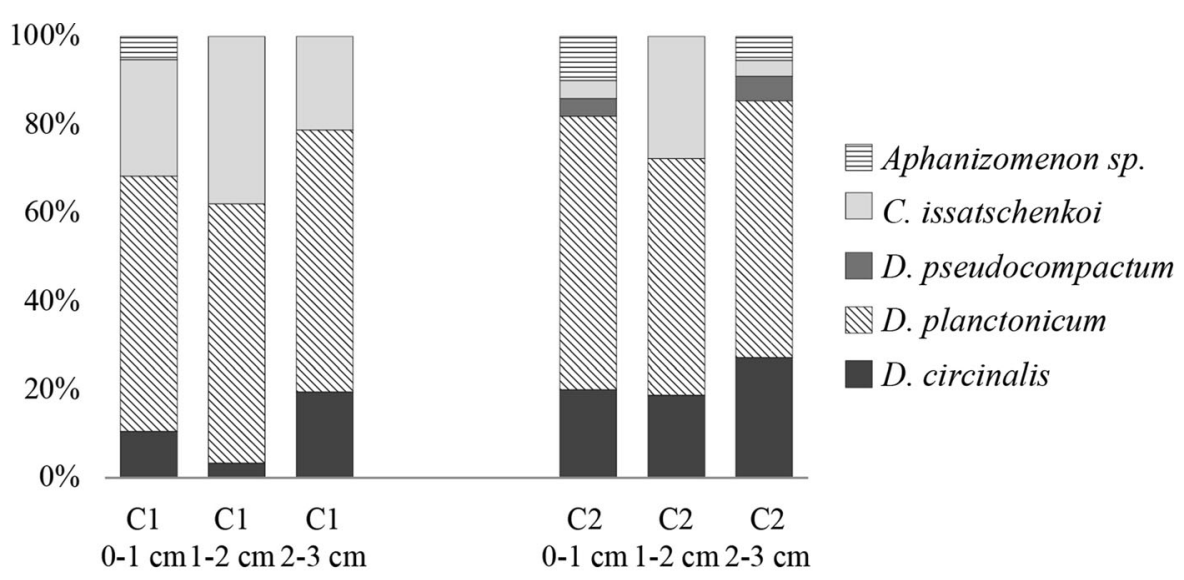

Fig. 7 Relative filament abundance for the cyanobacteria species of the Order Nostocales at the end of the germination experiment (day 15), in both cores ( $\mathrm{C} 1$ and $\mathrm{C} 2$ ), and the three analyzed depths in near-surface sediments $(3-2,2-1,1-0 \mathrm{~cm})$

concentrations during the first 24 years after impoundment, but increased substantially, $>2.5 \times$ after 2003 .

The rise in pigments of photosynthetic sulfur bacteria, which thrive under extreme environmental conditions, such as anoxia and darkness or low light, suggests an increase in bottom anoxia after 2003. Though such $\mathrm{O}_{2}$-free conditions could have enhanced pigment preservation, the radiation absorption ratio $430 \mathrm{~nm}: 410 \mathrm{~nm}$, a proxy for pigment preservation, yielded consistent, high values throughout the core, indicating there had been no change in pigment preservation. Thus, higher pigment abundances in the core after 2003 reflect a real shift in productivity and are not a simple artifact of pigment preservation.

Given the high magnitude and frequency of blooms in the reservoir observed during regular water monitoring (O'Farrell et al. 2012; Bordet et al. 2017), we expected to find a higher relative increase in cyanobacteria over eukaryotic phytoplankton. We found, however, that cyanobacteria trends tracked shifts in the phytoplankton community as a whole, without there having been major community reorganization. The latter can result from seasonal alternation of phytoplankton groups observed in the reservoir, with high relative cyanobacteria dominance during warm periods and high relative dominance of eukaryotic algae during winter (Bordet et al. 2017). It is possible that lack of sub-annual (seasonal) resolution in the sediment record from Salto Grande reservoir precludes identification of a seasonal signal. We note that bloom magnitude in this reservoir is highest in the dendritic, shallower areas of the water body, compared to blooms in the river-like area, as the latter has higher flow and greater depth (O'Farrell et al. 2012; Bordet et al. 2017; Drozd et al. 2019).

Grazing pressure on phytoplankton was low from the year of dam construction (1979) until 2001, when it first significantly increased, then increased again after 2008. The onset of increased grazing (2001) coincided almost exactly with the expansion of the exotic bivalve Limnoperna fortunei, which was first detected in the reservoir in 2001, and by 2003 had reached densities up to 50,000 individuals $\mathrm{m}^{-2}$ (Boltovskoy et al. 2006). Cladoceran and copepod densities, however, were rather low, with annual records during 2004-2012 ranging from quasi-absent to 6 individuals $\mathrm{L}^{-1}$ (Boltovskoy et al. 2013). Hence, increased grazing seems to have been related more to bivalve expansion than to zooplankton grazing. Moreover, Cataldo et al. (2012) showed at the mesocosm scale, L. fortunei favors blooms of Microcystis by modifying nutrient concentrations and proportions, and by promoting the formation of larger cyanobacteria colonies. The bivalve is a filter feeder, capable of filtering $357 \mathrm{~mL}$ ind ${ }^{-1} \mathrm{~h}^{-1}$ at $28{ }^{\circ} \mathrm{C}$ (Frau et al. 2013), and studies of its stomach contents found that its diet was mostly composed by euglenoids, diatoms and green algae (Rojas Molina et al. 2010). Such selective grazing could indirectly favor cyanobacteria over eukaryotic algae. Hence, grazing pressure exerted by the exotic bivalve $L$. fortunei seems to promote, rather than control cyanobacteria growth. 
Several studies suggest that water quality in the Salto Grande reservoir declined in the 24 years after its construction, including a more than two-fold increase in cyanobacteria (and other phytoplankton) productivity, an increase in photosynthetic sulfur bacteria (though still low in concentration) and an increase in sedimentation rate. These results underscore that degradation of this sub-tropical reservoir occurred over the course of decades, as has been recorded in tropical reservoirs elsewhere (Wengrat et al. 2018).

Historical environmental data show that for the period 1967-2017, air temperature increased significantly and wind speed decreased significantly by $44 \%$, whereas precipitation remained unchanged. The increase in air temperature was $0.5-1.0^{\circ} \mathrm{C}$ and was higher after 1993. Higher temperatures may enhance cyanobacteria growth through direct effects on growth rate (Paerl 2017) and through interactive effects with nutrients (Wagner and Adrian 2009) and wind. Indeed, in the Salto Grande reservoir, Bordet et al. (2017) observed that cyanobacteria surface blooms developed whenever temperature was above $16.5^{\circ} \mathrm{C}$ and wind speed was $\leq 3.5 \mathrm{~km} \mathrm{~h}^{-1}$. Current mean annual wind speeds are $<3.5 \mathrm{~km} \mathrm{~h}^{-1}$, favoring the establishment of cyanobacteria that develop scum-type blooms that accumulate on the surface (Microcystis spp. and Dolichospermum spp. complex). Water discharge and water level showed similar trends during the period analyzed, the 23 years between 1994 and 2017 , though this time frame may be too short to detect statistical changes. Cultural eutrophication was not assessed in this study, as the historical nutrient record is incomplete. Nevertheless, the water body is eutrophic (Table 1) and the area has experienced major changes in land use in the last 30 years (Drozd and Arturi 2017), and major increases in population, which probably affected nutrient concentrations in the reservoir.

The akinete (dormant cells) seed bank in the upmost sediments was large, and displayed concentrations similar to values in other reservoirs that experience cyanobacteria blooms (Cirés et al. 2013). Indeed, water bodies with large populations of planktonic cyanobacteria of the Order Nostocales usually contain large numbers of akinetes in their sediments (Hellweger et al. 2008). We found no Microcystis colonies in the sediments, even though sampled during a bloom, suggesting that this genus is unable to survive in deep-water sediments $(17 \mathrm{~m})$ of the river-like area, even during the growing season. This finding is not surprising, as Microcystis is unable to produce dormant cells. In laboratory conditions we observed germination from near-surface sediments of five Nostocales species, underscoring the capacity of this group of cyanobacteria to recolonize the plankton from inocula in sediments, under favorable conditions. In situ germination in the river-like area, however, could be less successful because of less favorable environmental conditions, relative to those in the laboratory. Two of the Dolichospermum species found in the sediments were described as dominant in the water column of the reservoir by O'Farrell et al. 2012), where mostly scum-forming blooms develop (Dolichospermum and Microcystis complexes) (O'Farrell et al. 2012; Bordet et al. 2017). Moreover, the relative dominance of the germling community, $76 \%$ Dolichospermum spp., reflected closely the dominance patterns observed in the water column by O'Farrell et al. (2012) and Bordet et al. (2017).

Acknowledgements DG acknowledges a grant from the Comisión Administradora del Río Uruguay (CARU) and PTP acknowledges funding from PIP 0236 (CONICET). We are grateful to the Comisión Técnica Mixta de Salto Grande for providing: (1) financial assistance to date the sediments, (2) the boat for sampling, and (3) historical data on water flow and water depth. We thank the Instituto Nacional de Tecnología Agropecuaria (INTA) for providing historical data on rainfall, wind speed and air temperature. We are grateful to Allyson Hutchens for language revision. We thank the Editor and two anonymous reviewers for their feedback and comments, which improved our work.

\section{References}

Amé MV, Diaz MD, Wunderlin DA (2003) Occurrence of toxic cyanobacterial blooms in San Roque reservoir (Córdoba, Argentina): a field and chemometric study. Environ Toxicol 18:192-201

Appleby PG (2001) Chronostratigraphic techniques in recent sediments. In: Last WM, Smol JP (eds) Tracking environmental change using lake sediments, vol 1. Basin analysis, coring, and chronological techniques. Kluwer Academic Publishers, Dordrecht, pp 171-203

Appleby PG, Oldfield F (1983) The assessment of ${ }^{210} \mathrm{~Pb}$ from sites with varying sediment accumulation rates. Hydrobiologia 103:29-35

Bennett KD (1996) Determination of the number of zones in a biostratigraphical sequence. New Phytol 132:155-170 
Berón LE (1990) Features of the limnological behavior of Salto Grande's reservoir (Argentina-Uruguay). Ecol Model 52:87-102

Birks HJB, Gordon AD (1985) Numerical methods in quaternary pollen analysis. Academic Press, London

Boltovskoy D, Correa N, Cataldo D, Sylvester F (2006) Dispersion and ecological impact of the invasive freshwater bivalve Limnoperna fortunei in the Río de la Plata watershed and beyond. Biol Invasions 8:947-963

Boltovskoy D, Correa N, Bordet F, Leites V, Cataldo D (2013) Toxic Microcystis (cyanobacteria) inhibit recruitment of the bloom-enhancing invasive bivalve Limnoperna fortunei. Freshw Biol 58:1968-1981

Bordet F, Fontanarrosa MS, O'Farrell I (2017) Influence of light and mixing regime on bloom-forming phytoplankton in a subtropical reservoir. River Res Appl 33:1315-1326

Carpenter SR, Christensen DL, Cole JJ, Cottingham KL, He X, Hodgson JR, Kitchell JF, Knight SE, Pace ML, Post DM, Schindler DE, Voichick N (1995) Biological control of eutrophication in lakes. Environ Sci Technol 29:784-786

Cataldo D, Vinocur A, O'Farrell I, Paolucci E, Leites V, Boltovskoy D (2012) The introduced bivalve Limnoperna fortunei boosts Microcystis growth in Salto Grande reservoir (Argentina): evidence from mesocosm experiments. Hydrobiologia 680:25-38

Chalar G (2006) Eutrophication dynamics on different temporary scales: Salto Grande reservoir (Argentina-Uruguay). In: Tundisi JG, Matsumura-Tundisi T, Sidagis C (eds) Eutrophication in South America: causes, consequences and technologies for management and control. International Institute of Ecology, São Carlos, pp 87-101

Chalar G (2009) The use of phytoplankton patterns of diversity for algal bloom management. Limnologica 39:200-208

Cirés S, Wörmer L, Agha R, Quesada A (2013) Overwintering populations of Anabaena, Aphanizomenon and Microcystis as potential inocula for summer blooms. J Plankton Res 35:1254-1266

de Tezanos PP, Litchman E (2010a) Interactive effects of N: P ratios and light on nitrogen-fixer abundance. Oikos 119:567-575

de Tezanos PP, Litchman E (2010b) Eco-physiological responses of nitrogen-fixing cyanobacteria to light. Hydrobiologia 639:63-68

Dearing JA (2013) Why future Earth needs lake sediment studies. J Paleolimnol 49:537-545

Drozd A, Arturi M (2017) Dinámica de los cambios en los patrones de coberturas/usos del suelo, entre 1985 y 2015, Federación, Entre Ríos: Patrón de cambios en las superficies forestadas y otras coberturas/usos y su relación a órdenes de suelos. Informe elaborado desde el Laboratorio de Investigación de Sistemas Ecológicos y Ambientales (LISEA) de la Universidad Nacional de la Plata (UNLP) para la Comisión Técnica Mixta Salto Grande (CTM), Argentina

Drozd A, de Tezanos PP, Fernandez V, Bazzalo M, Bordet F, Ibaniez G (2019) Hyperspectral remote sensing monitoring of cyanobacteria blooms from the Salto Grande reservoir: high and medium spatial resolution satellite algorithms simulation. Mar Freshw Res. https://doi.org/10.1071/ MF18429
Frau D, Rojas Molina F, Devercelli M, José de Paggi S (2013) The effect of an invading filter-feeding bivalve on a phytoplankton assemblage in the Paraná system: a mesocosm experiment. Mar Behav Physiol 45:303-316

Gilbert RO (1987) Statistical methods for environmental pollution monitoring. Van Nostrand Reinhold, New York

Guilizzoni P (2012) Palaeolimnology: an introduction. In: Gopal B (ed) Limnology of rivers and lakes. Encyclopedia of Life Support Systems (EOLSS), UNESCO, EOLSS Publishers, Oxford

Guillard RRL (1975) Culture of phytoplankton for feeding marine invertebrates. In: Smith WL, Chantey MH (eds) Culture of marine invertebrate animals. Plenum Publishers, New York, pp 29-60

Heiri O, Lotter AF, Lemcke G (2001) Loss on ignition as a method for estimating organic and carbonate content in sediments: reproducibility and comparability of results. J Paleolimnol 25:101-110

Hellweger FL, Kravchuk E, Novotny V, Gladyshev M (2008) Agent-based modeling of the complex life cycle of a cyanobacterium (Anabaena) in a shallow reservoir. Limnol Oceanogr 53:1227-1241

Huisman JM, Matthijs HCP, Visser PM (2005) Harmful cyanobacteria. Springer aquatic ecology, series 3. Springer, Dordrecht

Ibelings BW, Havens KE (2008) Cyanobacterial toxins: a qualitative meta-analysis of concentrations, dosage and effects in freshwater, estuarine and marine biota. In: Hudnell HK (ed) Cyanobacterial harmful algal blooms: state of the science and research needs. advances in experimental medicine and biology. Springer, New York, pp 675-732

IPCC (2014) Cambio climático 2014: Informe de síntesis. Contribución de los Grupos de Trabajo I, II y III al Quinto Informe de Evaluación del Grupo Intergubernamental de Expertos sobre el Cambio Climático. IPCC, Ginebra, Suiza

Joung SH, Oh HM, Ko SR, Ahn CY (2011) Correlation between environmental FACTORS and toxic and non-toxic $\mathrm{Mi}$ crocystis dynamics during bloom in Daechung Reservoir, Korea. Harmful Algae 10:188-193

Kalff J (2002) Limnology: inland waters ecosystems. Prentice Hall Publishers, Upper Saddle River, NJ

Kawamura N, Oda H, Ikehara K, Yamazaki T, Shioi K, Taga S, Hatakeyama S, Torii M (2007) Diagenetic effect on magnetic properties of marine core sediments from the southern Okhotsk Sea. Earth Planets Space 59:83-93

Kowalewski GA, Kornijów R, McGowan S, Kaczorowska A, Bałaga K, Namiotko T, Gąsiorowski M, Wasiłowska A (2016) Disentangling natural and anthropogenic drivers of changes in a shallow lake using palaeolimnology and historical archives. Hydrobiologia 767:301-320

Lami A, Guilizzoni P, Marchetto A (2000) High resolution analysis of fossil pigments, carbon, nitrogen and sulphur in the sediment of eight European Alpine lakes: the MOLAR project. J Limnol 59:15-28

Lami A, Musazzi S, Marchetto A, Buchaca T, Kernan M, Jeppesen E, Guilizzoni P (2009) Sedimentary pigments in 308 alpine lakes and their relation to environmental gradients. Adv Limnol 62:217-238

Leavitt PR, Sanford PR, Carpenter SR, Kitchell JF, Benkowski D (1993) Annual fossil records of food-web manipulation. 
In: Carpenter SR, Kitchell JF (eds) The trophic cascade in lakes. Cambridge University Press, Cambridge, pp 278-309

Legrand B, Le Jeune AH, Colombet J, Thouvenot A, Latour D (2017) Akinetes may be representative of past nostocalean blooms: a case study of their benthic spatiotemporal distribution and potential for germination in a eutrophic lake. Appl Environ Microbiol 83:1-14

Li Z, Yu J, Yang M, Zhang J, Burch MD, Han W (2010) Cyanobacterial population and harmful metabolites dynamics during a bloom in Yanghe Reservoir, North China. Harmful Algae 9:481-488

MacKenzie AB, Hardie SML, Farmer JG, Eades LJ, Pulford ID (2011) Analytical and sampling constrains in ${ }^{210} \mathrm{~Pb}$ dating. Sci Total Environ 409:1298-1304

McCall PI, Robbins JA, Matisoff G (1984) ${ }^{137} \mathrm{Cs}$ and ${ }^{210} \mathrm{~Pb}$ transport and geochronologies in urbanized reservoirs with rapidly increasing sedimentation rates. Chem Geol 44:33-66

McGowan S (2013) Pigment studies. In: Elias SA (ed) Encyclopedia of quaternary science, 2 nd edn. Elsevier, Amsterdam, pp 326-338

Merel S, Walker D, Chicana R, Snyder S, Baurès E, Thomas O (2013) State of knowledge and concerns on cyanobacterial blooms and cyanotoxins. Environ Int 59:303-327

O'Farrell I, Izaguirre I (2014) Phytoplankton of the middle and lower stretches of the Uruguay River. Adv Limnol 65:113-126

O'Farrell I, Bordet F, Chaparro G (2012) Bloom forming cyanobacterial complexes co-occurring in a subtropical large reservoir: validation of dominant eco-strategies. Hydrobiologia 698:175-190

O'Neil JM, Davis TW, Burford MA, Gobler CJ (2012) The rise of harmful cyanobacteria blooms: the potential roles of eutrophication and climate change. Harmful Algae 14:313-334

Paerl HW (2017) Controlling harmful cyanobacterial blooms in a climatically more extreme world: management options and research needs. J Plankton Res 39:763-771

Paerl HW, Paul VJ (2012) Climate change: links to global expansion of harmful cyanobacteria. Water Res 46:1349-1363

Pennington W, Cambray RS, Eakins JD, Harkness DD (1976) Radionuclide dating of the recent sediments of Blelham Tarn. Freshw Biol 6:317-331
Rahman AKM, Al Bakri D, Ford P, Church T (2005) Limnological characteristics, eutrophication and cyanobacterial blooms in an inland reservoir, Australia. Lake Reserv Res Manag 10:211-220

Riedinger-Whitmore MA, Whitmore TJ, Smoak JM, Brenner M, Moore A, Curtis J, Schelske CL (2005) Cyanobacterial proliferation is a recent response to eutrophication in many Florida lakes: a paleolimnological assessment. Lake Reserv Manag 21:423-435

Rojas Molina F, Paggi JC, Devercelli M (2010) Zooplanktophagy in the natural diet and selectivity of the invasive mollusk Limnoperna fortunei. Biol Inv 12:1647-1659

Taranu ZE, Gregory-Eaves I, Leavitt PR, Bunting L, Buchaca T, Catalan J, Domaizon I, Guilizzoni P, Lami A, McGowan S, Moorhouse H, Morabito G, Pick FR, Stevenson MA, Thompson PL, Vinebrooke RD (2015) Acceleration of cyanobacterial dominance in north temperate-subarctic lakes during the Anthropocene. Ecol Lett 18:375-384

Te SH, Gin KYH (2011) The dynamics of cyanobacteria and microcystin production in a tropical reservoir of Singapore. Harmful Algae 10:319-329

Thompson R, Oldfield F (1986) Environmental magnetism. Allen \& Unwin Ltd., London

Wagner C, Adrian R (2009) Quantifying the effects of climate change. Limnol Oceanogr 54:2460-2468

Wengrat S, Padial AA, Jeppesen E, Davidson TA, Fontana L, Costa-Böddeker S, Bicudo DC (2018) Paleolimnological records reveal biotic homogenization driven by eutrophication in tropical reservoirs. J Paleolimnol 60:299-309

Williamson CE, Saros JE, Warwick FV, Smol JP (2009) Lakes and reservoirs as sentinels, integrators, and regulators of climate change. Limnol Oceanogr 54:2273-2282

Znachor P, Jurczak T, Komárková J, Jezberová J, Mankiewicz J, Kaštovská K, Zapomělová E (2006) Summer changes in cyanobacterial bloom composition and microcystin concentration in eutrophic Czech reservoirs. Environ Toxicol 21:236-243

Publisher's Note Springer Nature remains neutral with regard to jurisdictional claims in published maps and institutional affiliations. 